\title{
Carbon Dioxide Separation from Flue Gas By Phase Enhanced Absorption
}

\author{
$(2004.7-2007.6)$
}

\author{
Annual Report \\ Reporting Period Start Date: 7/1/2004 \\ Reporting Period End Date: 6/30/2005 \\ Principal Author: Dr. Liang Hu \\ Student: $\quad$ Victor Roberts, Jr. \\ Monica J. Wood \\ DOE Project Manager: Tim Four
}

October 2005

DOE Awarding Number: DE-FG26-04NT42128

School of Engineering and Technology

Hampton University

Hampton, VA 23668 


\section{DISCLAIMER}

This report was prepared as an account of work sponsored by an agency of the United States Government. Neither the United States Government nor any agency thereof, nor any of their employees, makes any warranty, express or implied, or assumes any legal liability or responsibility for the accuracy, completeness, or usefulness of any information, apparatus, product, or process disclosed, or represents that its use would not infringe privately owned rights. Reference herein to any specific commercial product, process, or service by trade name, trademark, manufacturer, or otherwise does not necessarily constitute or imply its endorsement, recommendation, or favoring by the United State or reflect those of the United States Govemment or any agency thereof. 


\section{ABSTRACT}

A new process, phase enhanced absorption, was invented. The method is carried out in an absorber, where a liquid carrier (aqueous solution), an organic mixture (or organic compound), and a gas mixture containing a gas to be absorbed are introduced from an inlet. Since the organic mixture is immiscible or at least partially immiscible with the liquid carrier, the organic mixture forms a layer or small parcels between the liquid carrier and the gas mixture. The organic mixture in the absorber improves mass transfer efficiency of the system and increases the absorption rate of the gas. The organic mixture serves as a transportation media. The gas is finally accumulated in the liquid carrier as in a conventional gas-liquid absorption system.

The presence of the organic layer do not hinder the regeneration of the liquid carrier or recovery of the gas because the organic layer is removed by a settler after the absorption process is completed. In another aspect, the system exhibited increased gasliquid separation efficiency, thereby reducing the costs of operation and maintenance.

Our study focused on the search of the organic layer or transportation layer to enhance the absorption rate of carbon dioxide. The following systems were studied, (1) $\mathrm{CO}_{2}$-water system and $\mathrm{CO}_{2}$-water-organic layer system; (2) $\mathrm{CO}_{2}$-Potassium Carbonate aqueous solution system and $\mathrm{CO}_{2}$-Potassium Carbonate aqueous solution-organic layer system. $\mathrm{CO}_{2}$ water and $\mathrm{CO}_{2}$-Potassium Carbonate systems are the traditional gas-liquid absorption processes. The $\mathrm{CO}_{2}$-water-organic layer and $\mathrm{CO}_{2}$-Potassium Carbonateorganic layer systems are the novel absorption processes, phase enhanced absorption. As we mentioned early, organic layer (transportation layer phase) is used for the increase of absorption rate. Our study showed that the absorption rate can be increased by adding the organic layer. However, the enhanced factor is highly depended on the liquid mass transfer coefficient. 


\section{TABLE OF CONTENT}

$\begin{array}{ll}\text { Introduction } & 10\end{array}$

$\begin{array}{ll}\text { Executive summary } & 14\end{array}$

$\begin{array}{ll}\text { Experimental } & 16\end{array}$

$\begin{array}{ll}\text { Results and discussion } & 18\end{array}$

$\begin{array}{lr}\text { Conclusion } & 20\end{array}$ 


\section{LIST OF GRAPHICAL MATERIALS}

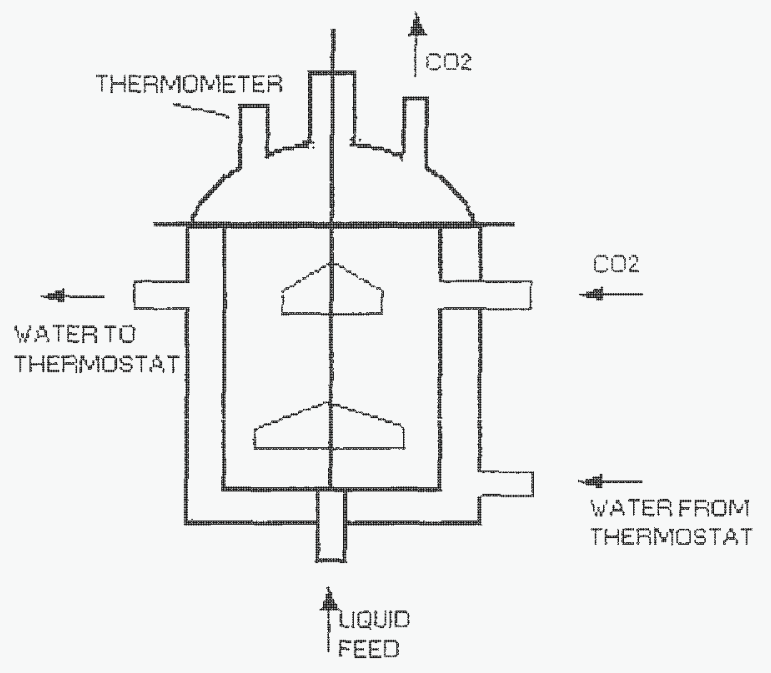

FIGURE 1 STIRRTNG CELI 


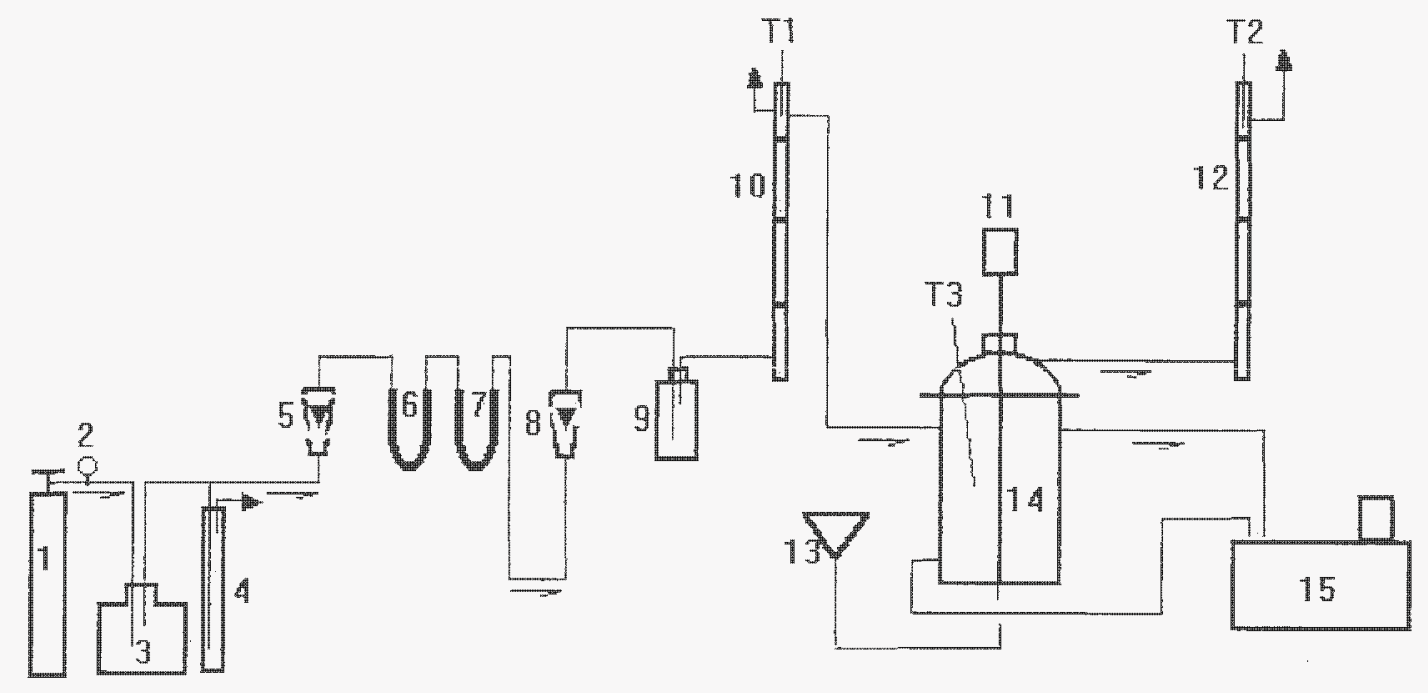

FIGURE 2 EXPERTIENTAL APPARATUS

1-CO2 CYLIMDER, 2-REGULATOR; 3- BURER BOTTLE; 4-PRESSURE STABLE TUBE;

5,8-ROTATIMG FLOW METER; $\delta$ - SILICON GEL U TUBE; 7 - ACTIVE CARBOH U TUBE;

9-SATURATOR; 10,12- FOAM FLM ILOW METER; 11- MOTOR 13-LIQUTD FEED FUMNEL; 14 - STIRRMG CELL: 15 -THERMOSTAT: T1.T2.T3-THERMOHETER 


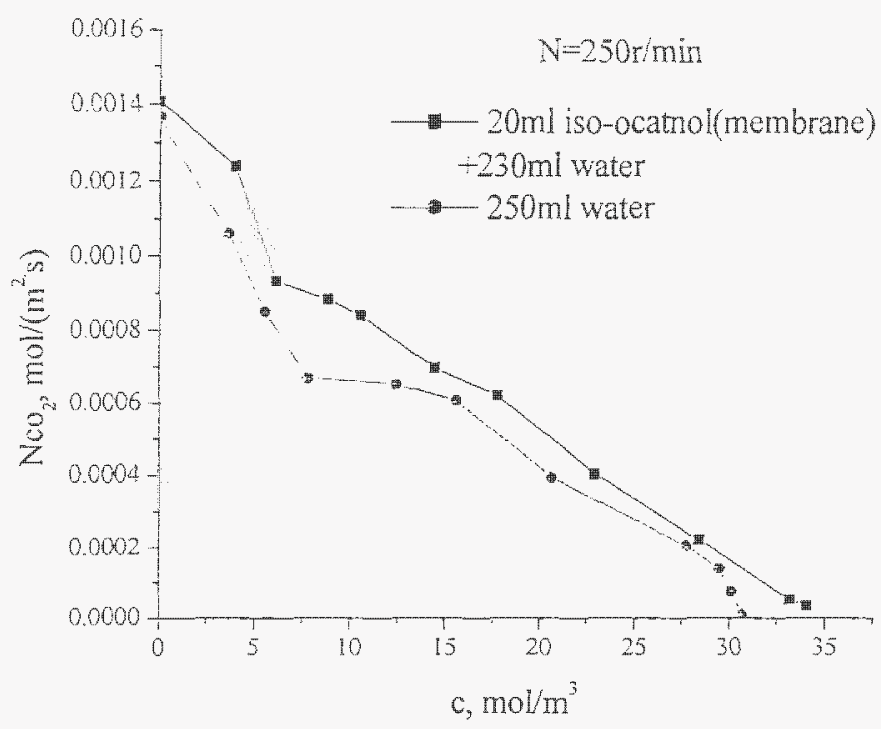

Figure 3. The comparison of $\mathrm{CO}_{2}$ absorption rate by water(black) and by water with isooctanol layer(red) at the agitation speed $250 \mathrm{rpm}$

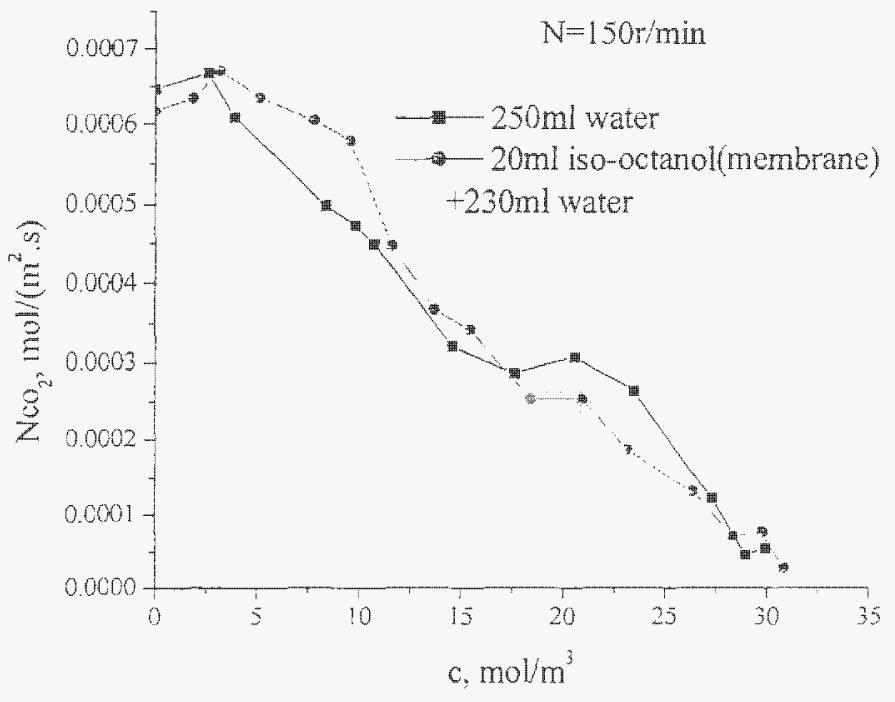

Figure 4. The comparison of $\mathrm{CO}_{2}$ absorption rate by water(black) and by water with isooctanol layer(red) at the agitation speed 150 rpm 


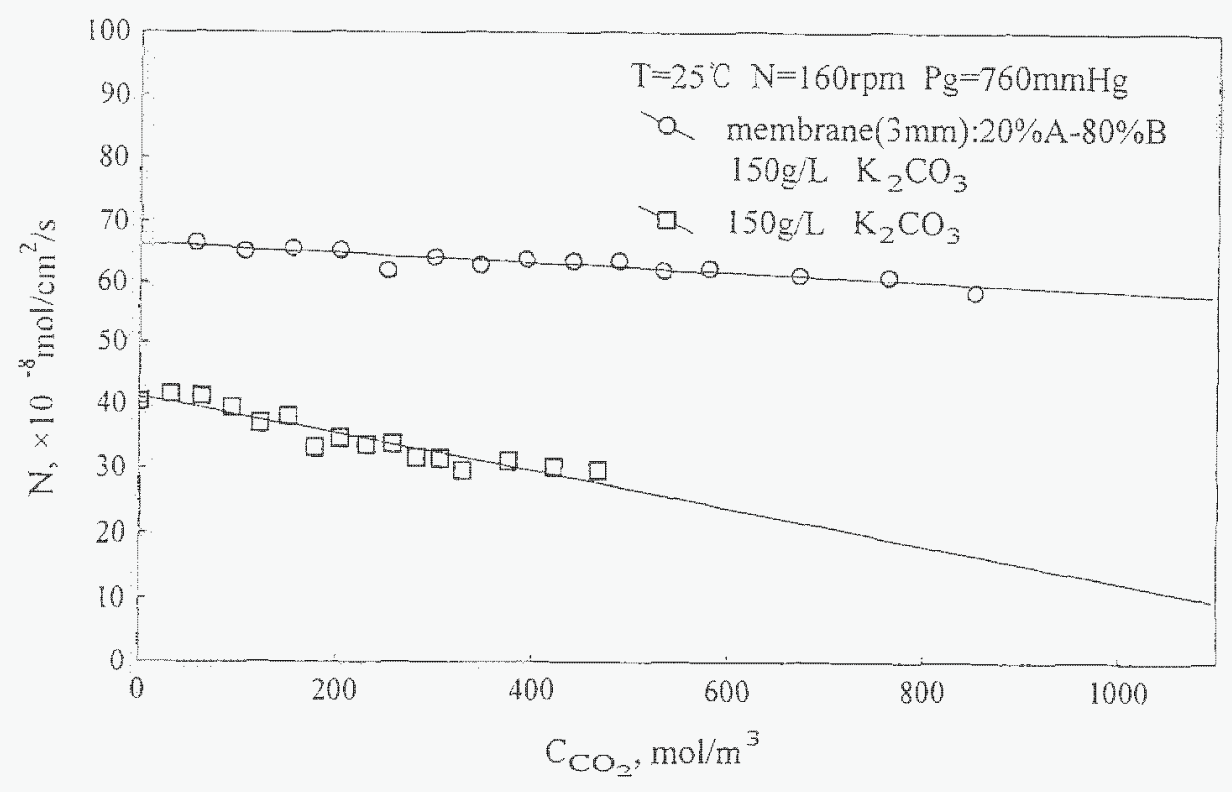

Figure 5. $\mathrm{CO}_{2}$ absorption rate by $150 \mathrm{~g} / 1 \mathrm{~K}_{2} \mathrm{CO}_{3}$ vs. by Phase Enhanced Absorption (liquid carrier: $150 \mathrm{~g} / \mathrm{K}_{2} \mathrm{CO}_{3}$; organic layer( $3 \mathrm{~mm}$ ): $20 \%$ amine $+80 \%$ solvent)

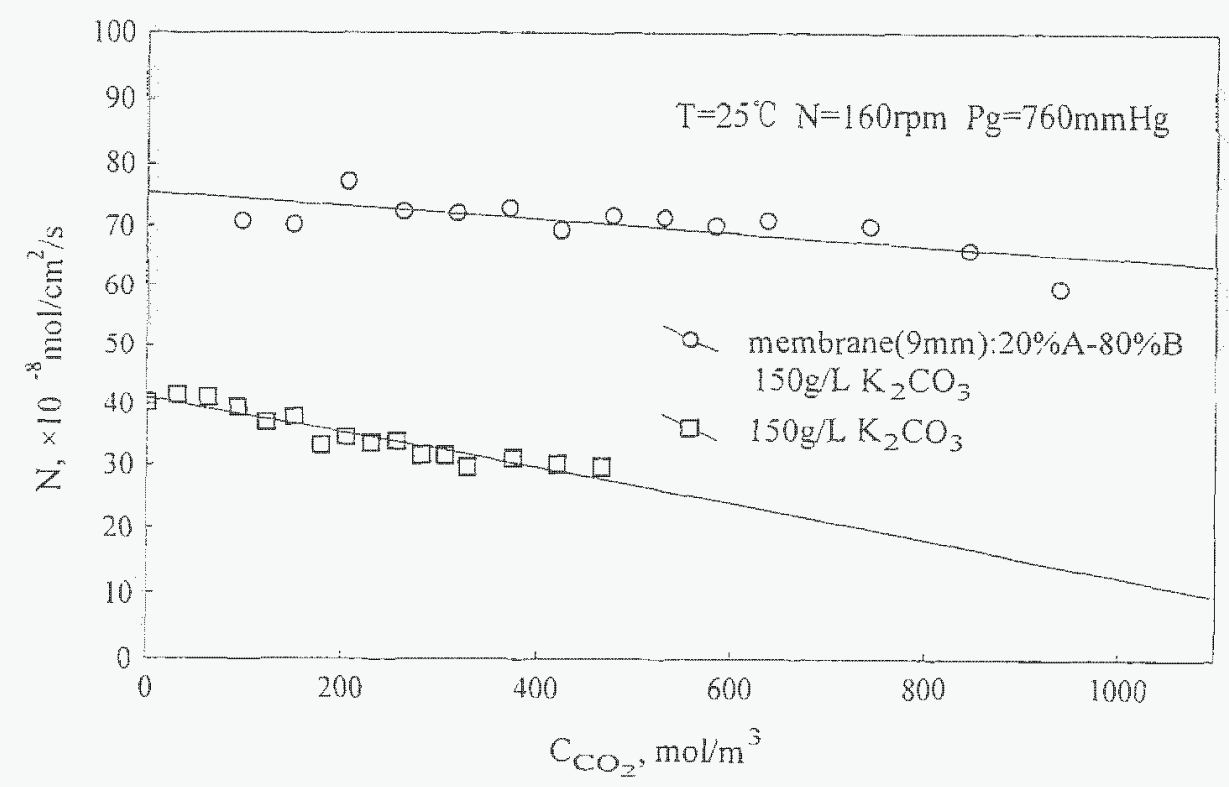

Figure 6. $\mathrm{CO}_{2}$ absorption rate by $150 \mathrm{~g} / \mathrm{K}_{2} \mathrm{CO}_{3}$ vs. by Phase Enhanced Absorption (liquid carrier: $150 \mathrm{~g} / 1 \mathrm{~K}_{2} \mathrm{CO}_{3}$; organic layer $(9 \mathrm{~mm}): 20 \%$ amine $+80 \%$ solvent) 


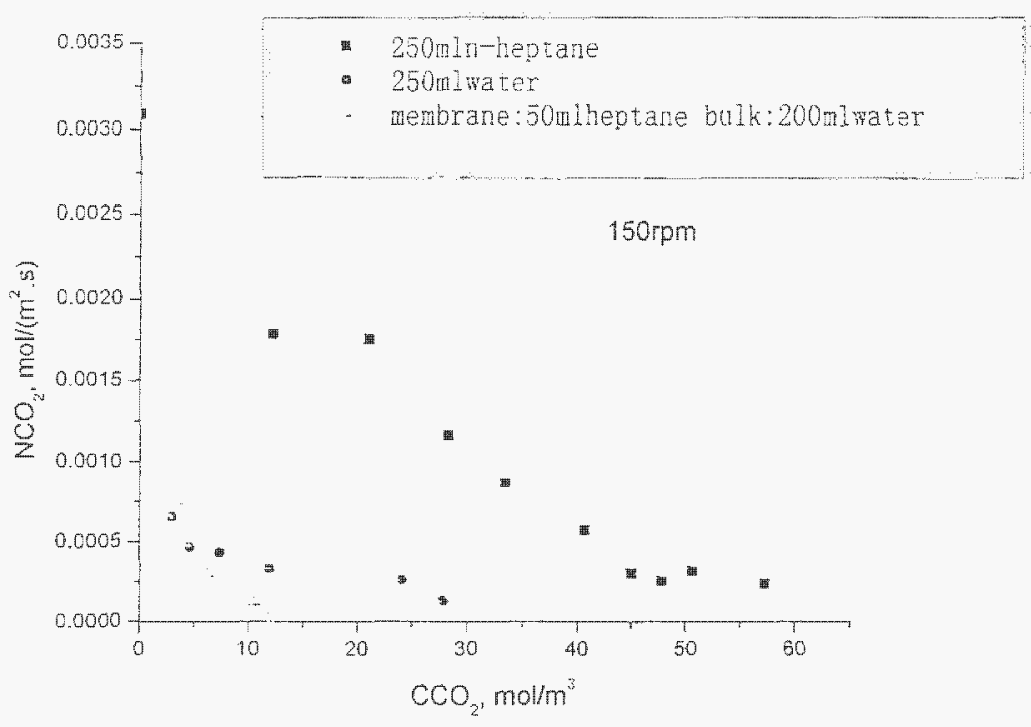

Figure 7. The comparison of $\mathrm{CO}_{2}$ absorption rates by water, by $n$-heptane and by water + n-heptane layer at the agitation speed of $150 \mathrm{rpm}$

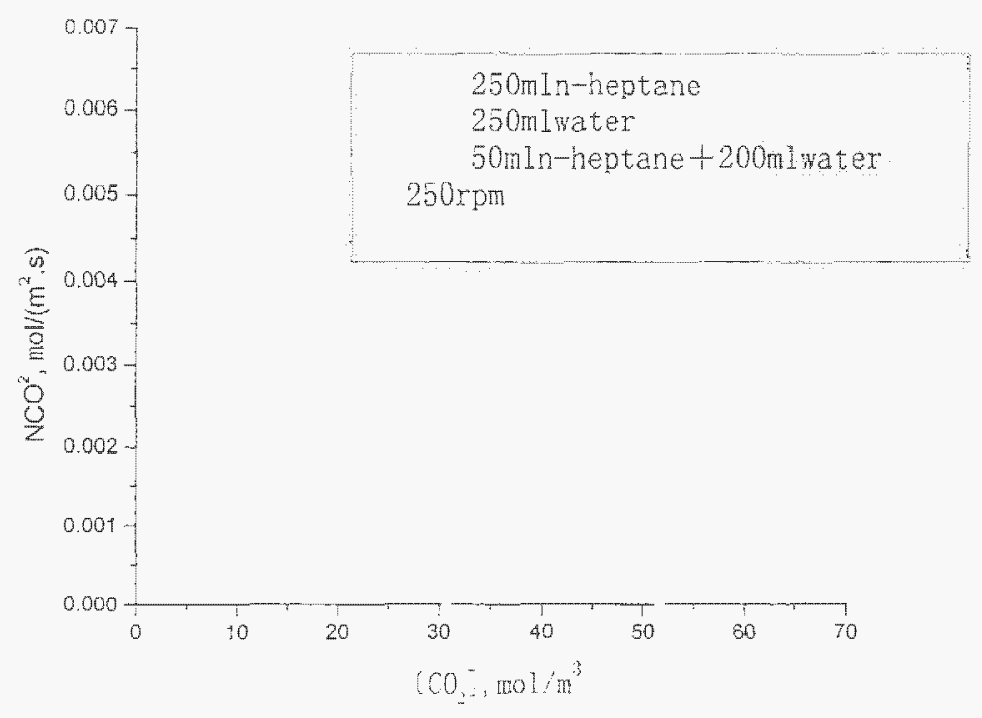

Figure 8 . The comparison of $\mathrm{CO}_{2}$ absorption rates by water, by n-heptane and by water $+\mathrm{n}$-heptane layer at the agitation speed of $150 \mathrm{rpm}$ 


\section{INTRODUCTION}

Among the methods used to separate and purify gases, the gas-liquid absorption method is one of the most powerful and efficient techniques. A conventional system designed to separate and purify gas consists of a gas phase (mixture of gas including the one to be isolated) and a liquid phase (solution that maximizes absorption).

In chemical absorption, the chemical compounds in the liquid solution react with the gas to form other compounds. This process serves two major purposes. First, chemical reaction with the gas can increase the carrying capacity of the absorbed gas. Second, it can reduce the mass transfer resistance or increase mass transfer coefficient. Both effects contribute to an increased absorption rate. However, such chemical reactions have setbacks: they hinder the release of the absorbed gas from the liquid solution.

Arthur L. Kohl and Fred C. Riesenfeld[1] in their book "Gas Purification," Gulf Publishing Company (1985) at page 235, discuss the effects of promoters or activators on the carbon dioxide absorption rate and vapor-liquid equilibria. Compared with hot potassium carbonate solutions, diethanolamine (DEA) and sterically hindered amines were found to be very effective in increasing the absorption rate of carbon dioxide. However, the partial pressure of carbon dioxide at equilibrium decreases after an activator is added into the carbonated solution. This means that it is more difficult to recover carbon dioxide from the activated solution than from a solution containing no activator.

Although amine compounds are commonly added into the aqueous solution of alkaline salts in a conventional absorption system, these types of absorbents have 
numerous setbacks. They increase the difficulty of carbon dioxide regeneration from the liquid carrier. The method discussed in this report, the phase enhanced absorption,

significantly increases the absorption rate of carbon dioxide. At the same time, adding an organic layer to the conventional system does not further hinder regeneration.

\section{Theory}

Absorption is a process by which one or more components of a gas mixture are transferred to a liquid where it is soluble. There are two types of absorption: they differ by the nature of the interaction between absorbent and absorbate. In the process of a physical absorption, the gas component being absorbed is simply dissolved in the liquid absorbent. However, the solute does not react chemically with the absorbent. In the case of chemical absorption, there is a chemical reaction between the gas component being absorbed and a component in the liquid to form a compound. In a chemical absorption, the chemical reaction between the gas solute and some component in the liquid solution enhances the absorption rate of the gas.

The phase enhanced absorption features an organic compound in addition to the traditional gas and liquid components. Adding an organic compound or mixture into the absorption system increases the absorption rate of the gas significantly. In phase enhanced absorption, more than one liquid phase is involved in absorbing the gas. One of the liquids serves as an absorbing solution (carrying phase), where the gas is ultimately accumulated. The other liquid, the transportation layer (transportation phase), plays the role of transporting the gas from the gas mixture to the absorbing solution and increasing the absorption rate of the gas. This transportation layer is composed of an organic 
compound and simply plays the role of accelerating the transport of the gas to be isolated (in the case carbon dioxide) from the gas phase to the carrying phase.

Due to the added organic layer, phase enhanced absorption has a unique mass transfer model. The gas to be isolated first separates from the bulk of the gas phase and comes in contact with the interface of the transportation phase. This liquid layers absorbs the gas. The absorption is either physical or chemical. In other words, while in the transportation phase, the gas solute may react with the components in transportation phase. In the next step, the gas solute dissolved in the transportation phase passes through the interface between the transportation phase and the carrying phase, and enters into carrying phase. Once the gas is in the carrying phase, the gas solute may exist in two forms: it may be physically dissolved or in a chemical compound resulting from a reaction between the gas and a component of the carrying phase.

The function of the transportation phase is to deliver gas solute from the gas phase to the carrying phase and to increase the absorption rate. Viewed with the film theory, the phase enhanced absorption mass transfer model can be summarized in the following sketch:

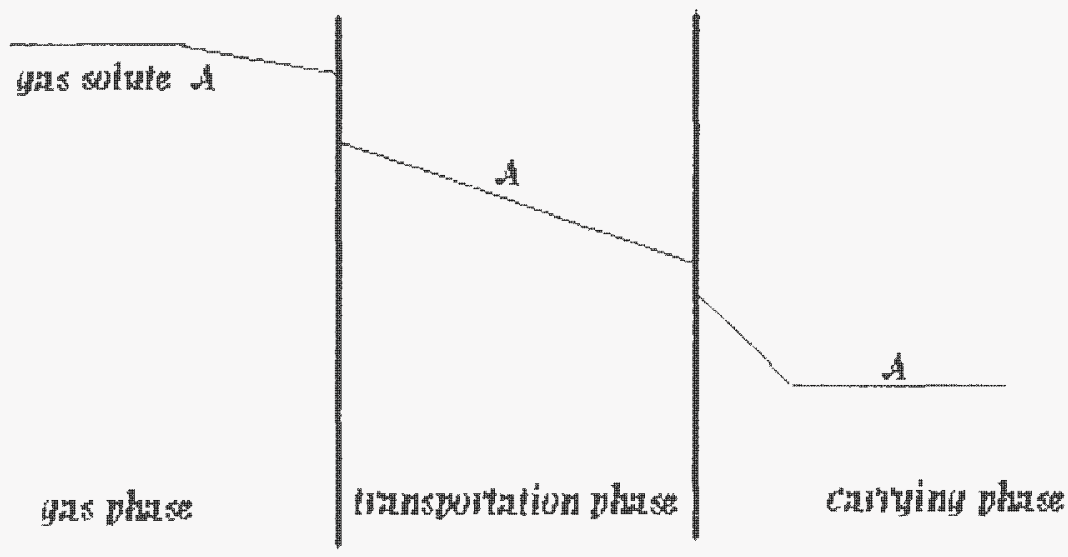

MASS TRANSFER MODEL 
This report examines the absorption rate of carbon dioxide with phase enhanced absorption and compares this rate to that of a conventional gas-liquid absorption method (without the transportation layer), In our experiments, carbon dioxide gas was ultimately absorbed by water and sodium carbonate aqueous solution(carrying phase). The experiments that follow are designed to demonstrate that adding a liquid phase consisting of an organic compound significantly improves the absorption rate of carbon dioxide. 


\section{EXECUTIVE SUMMARY}

Absorption is a process by which one or more components of a gas mixture are transferred to a liquid where it is soluble. There are two types of absorption: they differ by the nature of the interaction between absorbent and absorbate. In the process of a physical absorption, the gas component being absorbed is simply dissolved in the liquid absorbent. However, the solute does not react chemically with the absorbent. In the case of chemical absorption, there is a chemical reaction between the gas component being absorbed and a component in the liquid to form a compound. In a chemical absorption, the chemical reaction between the gas solute and some component in the liquid solution enhances the absorption rate of the gas.

The phase enhanced absorption features an organic compound in addition to the traditional gas and liquid components. Adding an organic compound or mixture into the absorption system increases the absorption rate of the gas significantly. In phase enhanced absorption, more than one liquid phase is involved in absorbing the gas. One of the liquids serves as an absorbing solution (carrying phase), where the gas is ultimately accumulated. The other liquid, the transportation layer (transportation phase), plays the role of transporting the gas from the gas mixture to the absorbing solution and increasing the absorption rate of the gas. This transportation layer is composed of an organic compound and simply plays the role of accelerating the transport of the gas to be isolated (in the case carbon dioxide) from the gas phase to the carrying phase.

Due to the added organic layer, phase enhanced absorption has a unique mass transfer model. The gas to be isolated first separates from the bulk of the gas phase and comes in contact with the interface of the transportation phase. This liquid layers absorbs the gas. The absorption is either physical or chemical. In other words, while in the transportation phase, the gas solute may react with the components in transportation phase. In the next step, the gas solute dissolved in the transportation phase passes through the interface between the transportation phase and the carrying phase, and enters into carrying phase. Once the gas is in the carrying phase, the gas solute may exist in two

forms: it may be physically dissolved or in a chemical compound resulting from a reaction between the gas and a component of the carrying phase.

The function of the transportation phase is to deliver gas solute from the gas phase to the carrying phase and to increase the absorption rate. Viewed with the film theory, the phase enhanced absorption mass transfer model can be summarized in the following sketch: 


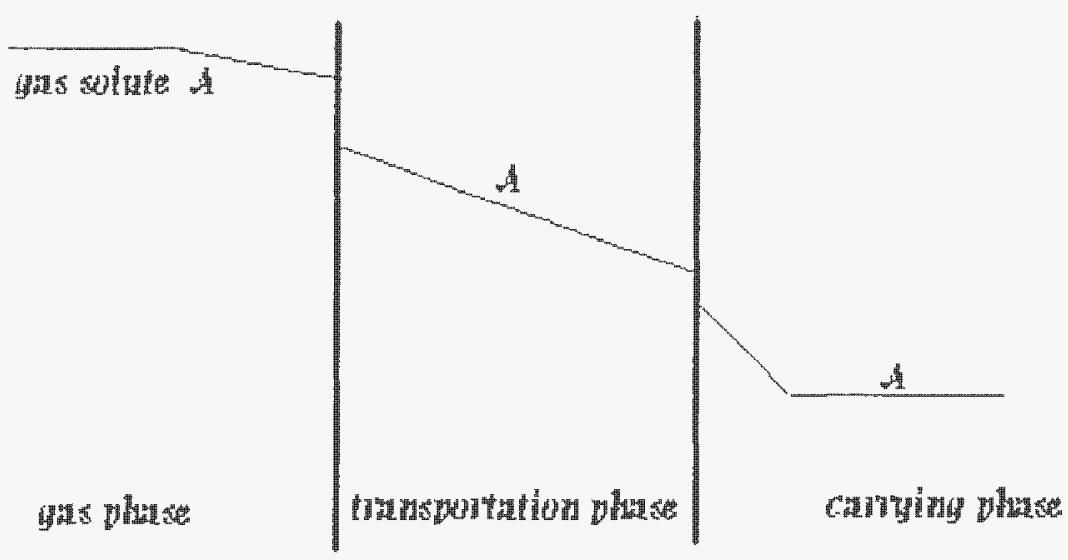

\section{MASS TRANSFER MODEL}

This report examines the absorption rate of carbon dioxide with phase enhanced absorption and compares this rate to that of a conventional gas-liquid absorption method (without the transportation layer). In our experiments, carbon dioxide gas was ultimately absorbed by water and sodium carbonate aqueous solution(carrying phase). The experiments that follow are designed to demonstrate that adding a liquid phase consisting of an organic compound significantly improves the absorption rate of carbon dioxide. 


\title{
EXPERIMENTAL
}

\section{Experimental Method and Apparatus}

\author{
Apparatus:
}

Phase enhanced absorption can be demonstrated using a simple system consisting of a stirring cell and a series of connected apparatus, all sketched and explained below. Figure 1 is a sketch of a stirring cell, the most important component that includes the three phases unique to the phase enhanced absorption method. The remaining apparatus necessary to measure the absorption rate is sketched in Figure 2. The stirring cell described is also identified in Figure 2.

The stirring cell, made of glass, contains all three phases of a phase enhanced absorption system (gas phase, organic layer, and aqueous solution). The cell's inner diameter is $121 \mathrm{~mm}$ and its depth is $130 \mathrm{~mm}$. Two agitating blades, one for the aqueous phase, one for the gas phase, are driven by a direct current motor. The agitating speed is monitored. The rest of the experimental apparatus is shown in Figure 2. The function of each component of the experimental system is explained below.

Method:

To measure the absorption rate of carbon dioxide in the system maintained in the stirring cell. the gas originating from the initial cylinder must pass through the series of apparatus to flow out of the flow meter (12). First, the carbon dioxide cylinder (1) releases carbon dioxide, which passes through the buffer bottle (3) and the pressure stable tube (4). The gas flow rate is controlled and measured by the rotating flow meters ( 5 and 8). The gas clean system consists of two U tubes. The first $U$ tube (6) is filled with silicon gel and the second $\mathrm{U}$ tube $(7)$ is filled with active carbon. The gas is saturated 
with moisture by the saturator (9). The solution in the saturator is the same solution that is in the stirring cell (14). Gas flow rate is measured by the foam film flow meters ( 10 and 12) before and after absorption in the stirring cell (14). The difference between two flow rates is the gas absorption rate. After the measurement, the carbon dioxide gas is released.

The absorption rate of gas, carbon dioxide, at time twas determined by the difference of two flow rates, in and out of stirring cell with two foam film flow meters. As the results of the measurement, the relationship of absorption rate $r$ and time $t$ would be obtained. Integration of absorption rate with time, $r \sim t$, the total amount of carbon dioxide absorbed into the liquid phase can be obtained.

Experimental steps:

(1) Measure the flow rate of gas in and out of the absorption cell at the same time (volume flow rate);

(2) Measure the temperature of each foam film flow meter $\mathrm{T} 1$ and $\mathrm{T} 2$;

(3) Use idea gas equation to calculate the mass flow rates $r 1$ and $\mathbf{r} 2[\mathrm{~mol} / \mathrm{s}]$;

(4) Subtract the flow rate of gas in and out of the absorption cell, which is equal to the absorption rate $\mathrm{r}$.

Calculation:

The idea gas equation: $\quad P V=n R T$

Divide by time $t: \quad \mathrm{PV} / \mathrm{t}=\mathrm{RTn} / \mathrm{t}$

The mass flow rate: $n / t=P V /(t R T)$

Subtract mass flow rate of in and out of absorption cell, which is the absorption rate: 
$r=r l-r 2=(n / t)_{1}-\left(n / t_{2}=P V_{1} /\left(t R T_{1}\right)-P V_{2} /\left(t R T_{2}\right)\right.$

where $t(s)$ is the eclipsed time.

The absorption rate per square area of gas-liquid interface $\mathrm{N}\left[\mathrm{mol} /\left(\mathrm{m}^{2} \cdot \mathrm{s}\right)\right]$ :

$$
N=\text { rarea of gas-liquid interface }
$$

$\mathrm{CO}_{2}$ concentration in liquid $\mathbf{c}$ :

$$
c=i r d t \text { (from } 0 \text { to } t)
$$

\section{RESULTS AND DISCUSSION}

\section{1. $\mathrm{CO}_{2}$-water system and $\mathrm{CO}_{2}$-water-isooctanol system}

$\mathrm{CO}_{2}$-water system is a traditional absorption process. $\mathrm{CO}_{2}$ is absorbed into water.

This is a physical absorption. $\mathrm{CO}_{2}$-water-isooctanol system is a phase enhanced

absorption process, where isooctanol forms organic layer between $\mathrm{CO}_{2}$ gas and water to increase the $\mathrm{CO}_{2}$ absorption rate. $\mathrm{CO}_{2}$ absorption rate by water and by water with isooctanol layer were measured individually under the same experimental condition: the temperature $25 \mathrm{oC}$, pressure (pure $\mathrm{CO}_{2}$ gas used): $1 \mathrm{~atm}$, agitation speed: $250 \mathrm{rpm}$ and $150 \mathrm{rpm}$, and liquid volume: $250 \mathrm{ml}$. The experimental results are shown in Figure $3 \& 4$.

Figure 3 is the comparison of $\mathrm{CO}_{2}$ absorption rate by water and by water + isooctanol layer at the agitation speed $250 \mathrm{rpm}$. In Figure 3 , the line with square indicates the relationship between $\mathrm{CO}_{2}$ absorption rate by water and $\mathrm{CO}_{2}$ concentration in liquid. The line with diamond is the relationship between $\mathrm{CO}_{2}$ absorption rate by water + isooctanol layer and $\mathrm{CO}_{2}$ concentration in liquid. The liquid was agitated at the speed of $250 \mathrm{rpm}$ with the total liquid volume of $250 \mathrm{ml}(230 \mathrm{ml}$ water and $20 \mathrm{ml}$ isooctanol). As seen in Figure 3, the absorption rate by water + isooctanol layer is higher than that by water. 
Figure 4 is the comparison of $\mathrm{CO}_{2}$ absorption rate by water and by water with isooctanol laver at the agitation speed $150 \mathrm{mpm}$. In Figure 4, the line with square indicates the relationship between $\mathrm{CO}_{2}$ absorption rate by water and $\mathrm{CO}_{2}$ concentration in liquid. The line with diamond is the relationship between $\mathrm{CO}_{2}$ absorption rate by water + isooctanol layer and $\mathrm{CO}_{2}$ concentration in liquid. The total volume of the liquid was 250 $\mathrm{ml}(230 \mathrm{ml}$ water and $20 \mathrm{ml}$ isooctanol). As seen in Figure 4, the absorption rate by water

+ isooctanol layer is close to the absorption rate by water.

By comparing Figure 3 and Figure 4, the absorption rate by water with isooctanol layer is highly depended on the agitation speed. The reason is obvious. The liquid mass transfer resistance between water and isooctanol layer caused the absorption rate depression at lower agitation speed.

\section{2. $\mathrm{CO}_{2}$-potassium carbonate aqueous solution system and $\mathrm{CO}_{2}$-potassium carbonate aqueous solution-organic layer system}

Using organic layer to enhance $\mathrm{CO}_{2}$ absorption rate has being studied. The results are encouraged. Figure 5 and 6 showed that using organic solution in organic layer to enhance $\mathrm{CO}_{2}$ absorption rate. The composition of the organic layer was $20 \%$ activate agent and $80 \%$ other organic solvents. The liquid carrier was potassium carbonate aqueous solution $(150 \mathrm{~g} / \mathrm{l})$. The experiments were conducted at $25^{\circ} \mathrm{C}$, and 1 atm. $99.99 \%$ $\mathrm{CO}_{2}$ was used in absorption. Liquid was agitated to provide sufficient mass transfer. The experimental results showed that absorption rate was increased significantly after introducing organic layer into the potassium carbonate aqueous solution. Figure 5 showed the absorption rate $\mathrm{vs}$. $\mathrm{CO}_{2}$ concentration in potassium carbonate aqueous solution $(885 \mathrm{ml})$ at $3 \mathrm{~mm}$ thickness organic layer $(40 \mathrm{ml})$. Figure 6 showed the absorption rate vs. 
$\mathrm{CO}_{2}$ concentration in potassium carbonate aqueous solution $(800 \mathrm{ml})$ at $9 \mathrm{~mm}$ thickness organic layer $(120 \mathrm{ml})$. Both absorption results of phase enhanced absorption were compared with $\mathrm{CO}_{2}$ absorption rate by potassium carbonate aqueous solution at the same experimental conditions. As in Figure 5 and 6 , absorption rates by phase-enhanced absorption are significantly higher than that by traditional absorption.

\section{3. $\mathrm{CO}_{2}$-water system and $\mathrm{CO}_{2}$-water-n-haptane layer system}

Figure 7 is the comparison of $\mathrm{CO}_{2}$ absorption rates by water, by $n$-heptane and by water $+\mathrm{n}$-heptane layer at the agitation speed of $150 \mathrm{rpm}, \mathrm{CO}_{2}$ absotption rate by water + n-heptane layer was a slowest process. $\mathrm{CO}_{2}$ absorption by $n$-heptane had the highest rate. While at the agitation speed of $250 \mathrm{rpm}$ (see Figure 8 ), $\mathrm{CO}_{2}$ absorption rate by water $+\mathrm{n}$ heptane layer was higher than that by water along. In both agitation speeds, $\mathrm{CO}_{2}$ absorption by $n$-heptane had the highest rate. The experimental results showed that (1) introduction of $n$-heptane layer into $\mathrm{CO}_{2}$ - water absorption system is able to enhance the absorption rate by water, however the absorption rate is highly depended on the agitation speed, and (2) because of the higher $\mathrm{CO}_{2}$ absorption rate by n-haptane or lower mass transfer resistant between the interface of gas and n-haptane, the transportation layer of nhaptane delivers $\mathrm{CO}_{2}$ from gas phase into water phase and enhances the absorption rate as long as the sufficient mass transfer (agitation) between two liquid phases is provided.

\section{CONCLUTION}

Experiments comparing the absorption rate of a conventional gas-liquid

absorption system with that of a modified system using phase enhanced absorption show that phase enhanced absorption exhibits a higher absorption rate. 
The new system consists of a gas component (carbon dioxide), an organic layer, and an aqueous solution. The systems were studied, (1) $\mathrm{CO}_{2}$-water system and $\mathrm{CO}_{2}-$ water- isooctanol layer system; (2) $\mathrm{CO}_{2}$-Potassium Carbonate aqueous solution system and $\mathrm{CO}_{2}$-Potassium Carbonate aqueous solution-organic layer system; (3) $\mathrm{CO}_{2}$-water system and $\mathrm{CO}_{2}$-water-n-haptane layer system. $\mathrm{CO}_{2}$-water and $\mathrm{CO}_{2}$-Potassium Carbonate systems are the traditional gas-liquid absorption processes. The $\mathrm{CO}_{2}$-water-organic layer and $\mathrm{CO}_{2}$-Potassium Carbonate-organic layer systems are the novel absorption processes, phase enhanced absorption. As we mentioned early, organic layer (transportation layer phase) is used for the increase of absorption rate. Our study showed that the absorption rate can be increased significantly by adding the organic layer. However, the enhanced factor is highly depended on the liquid mass transfer coefficient. The mechanism is obvious because of the higher $\mathrm{CO}_{2}$ absorption rate by organic layer or lower mass transfer resistant between the interface of gas and organic layer, the transportation layer (organic layer) delivers $\mathrm{CO}_{2}$ from gas phase into water phase and enhances the absorption rate as long as the sufficient mass transfer (agitation) between two liquid phases is provided.

Prospects for future progress includes the kinetic and mechanism study, search for the potential application for $\mathrm{CO}_{2}$ capture. 